\title{
Research on Copper Indium Gallium Selenide (CIGS) Thin-Film Solar Cells
}

\author{
Jixiang Zhou ${ }^{1}$ and Changyu $\mathrm{Li}^{1 \text {,a }}$ \\ ${ }^{1}$ Guangzhou College of South China University of Technology, Guangzhou 510800, China
}

\begin{abstract}
As a new-style solar cell, copper indium gallium selenide (CIGS) thin-film solar cell owns excellent characteristics of solar energy absorption, and it is one of the widely used thin-film solar cells. This paper mainly focuses on the research progress of this type of solar cell. Firstly, its theoretical principles are briefly described. Then, its cell materials, configuration and fabrication procedure are introduced. Subsequently, the remarkable research work about CIGS solar cell are reviewed. Finally, its commercial status is illustrated, followed by the critical issues and future perspectives.
\end{abstract}

\section{Introduction}

The copper indium gallium selenide (CIGS) thin-film solar cell is a new type of solar cell developed in the late 1980 s $[1,2]$, which has been confirmed in laboratory research to obtain a theoretical photoelectric conversion efficiency of more than $20 \%$ [3]. This type of solar cell has high stability and excellent solar absorption characteristics, and has been commercialized, and it is one of the currently most widely commercialized thin-film solar cells [4].

\section{Theoretical principle}

Solar cell is a kind of photovoltaic device that can directly convert solar energy into electric current by absorbing photo-generated carriers in a semiconductor. In solar cells, three main processes are involved: generating charge carriers by absorbing photons, separating carriers, and collecting carriers. A semiconductor material often absorbs photons with energy greater than its band gap. The absorbed photons excite an electron to move from the valence band to the conduction band in the absorbing material, which creates an electron-hole pair. The generated charge carrier pairs are either recombined or separated and then collected. The absorbed photons depend on the thickness and absorption coefficient of the absorber material. The key part of the solar cell is the formation of the p-n junction, which consists of two semiconductor materials connected together, one of which is n-type doped and the other one is p-type doped. In CIGS solar cells, a variety of different semiconductor materials are used for the formation of $\mathrm{p}-\mathrm{n}$ junctions, so such structures are called heterojunctions. Using heterojunctions allows batteries to be provided with a wide band gap window layer, thereby reducing surface recombination. The valence band and conduction band have discontinuities and device structures that can be observed in the band diagram of the $p-n$ heterojunction. This kind of junction represents the possibility of the formation of energy barriers in the phenomenon of charge carrier transport. The conversion of minority carriers in the p-type absorber layer can decouple the physical and electronic junctions by the formation of buried junctions, thereby becoming majority carriers located on the adjacent interface zone, which also reduces the feasibility of recombination [4].

\section{Battery material, structure configuration and manufacturing process}

The active material of CIGS solar cells is composed of a direct band gap, tetrahedral bonded compound element semiconductor, which has a chalcopyrite crystal structure. By casting any proportion of $\mathrm{CuInSe} 2$ and $\mathrm{CuGaSe} 2$ into alloys, CIGS solar cells can be formed. However, most high-performance devices maintain the $\mathrm{Ga} /(\mathrm{In}+\mathrm{Ga})$ ratio between 0.25 and 0.35 , and adjust the band gap of $\mathrm{CuInSe} 2$ and $\mathrm{CuGaSe} 2$ to $1.04 \mathrm{eV}$ and $1.68 \mathrm{eV}$ respectively by changing the capacity of gallium $(\mathrm{Ga})$. At the beginning, CuInSe2 solar cell was just a simple p$\mathrm{CuInSe} 2 / \mathrm{n}-\mathrm{CdS}$ heterojunction. However, modern CIGS solar cells have been developed to have the following configurations: substrate, molybdenum electrode, CIGS, $\mathrm{CdS}, \mathrm{i}-\mathrm{ZnO}, \mathrm{AZO}$, aluminum metal electrode [5].

Under normal circumstances, CIGS solar cells will use soda lime glass to make a rigid substrate. However, flexible substrates (such as polyimide or metal foil) have also been widely used in this method. In CIGS solar cells, a sputtered Mo electrode layer will be used as the back contact layer and reflective layer to reflect the least absorbed light into the absorption layer; and a P-type CIGS absorbing layer is formed above the sputtered Mo

a Corresponding author: 644968790@qq.com 
electrode layer. In the state-of-the-art high-efficiency CIGS solar cell, the absorber layer is formed by physical vapor deposition (for example, thermal co-evaporation at a high temperature of $600^{\circ} \mathrm{C}$ ) and a two-stage process (for example, first the sputtering of the precursor layer, followed by the selenization of selenium vapor or $\mathrm{H} 2 \mathrm{Se}$ gas).

A thin n-type buffer layer is placed above the absorber layer. This buffer layer is usually $\mathrm{CdS}$ deposited using a chemical bath. However, considering the environment and harmful effects, scholars have carried out a lot of research to develop a cadmium-free buffer layer [6,7]. In these studies, $\mathrm{ZnSe}, \mathrm{ZnS}, \mathrm{ZnO},(\mathrm{Zn}, \mathrm{Mg}) \mathrm{O}, \mathrm{In}(\mathrm{OH}) 3$, In2S3, In2Se3, InZnSex, $\mathrm{SnS} 2, \mathrm{SnO} 2$, etc. were used as buffer layers, and these buffer layers use various preperation methods (for example, metal organic chemical vapor deposition, chemical bath deposition, electrodeposition, sputtering, thermal evaporation, atomic layer deposition, ion layer gas reaction, pulsed laser deposition, etc.) to be deposited [7]. To avoid surface damage of the $\mathrm{CdS}$ layer, an $\mathrm{i}-\mathrm{ZnO}$ layer was added above the buffer layer, and a relatively thick AZO (specifically $\mathrm{Al}: \mathrm{ZnO}$ ) layer was used to cover the $\mathrm{i}-\mathrm{ZnO}$ layer. The $\mathrm{ZnO}$ layer is deposited using only chemical vapor deposition. The AZO layer acts as a transparent conductive oxide layer to collect and transport electrons to the outside of the battery and emit as much light as possible.

\section{Research progress}

To show the development of CIGS thin-film solar cells, the following section mainly reviews some key research work done by domestic and foreign researchers in this field.

The history of CIGS thin-film solar cells can be traced back to the first $\mathrm{CuInSe} 2$ (CIS) thin film synthesized by Hahn in 1953 [8]. Bell Labs nominated this material as a photovoltaic material in 1974. In 1974, a researcher coated an evaporated n-type CdS on top of a p-CuInSe 2 single crystal, thereby developing the first $\mathrm{CuInSe} 2 / \mathrm{CdS}$ heterojunction photovoltaic device [9]. In 1976, the University of Maine developed a p-CuInSe $2 / n-C d S$ photovoltaic cell with a rigid substrate, and made the first significant progress in the efficiency of CIGS thin-film solar cells, with a reported efficiency of $4.5 \%$ [10]. In 1981, Boeing developed the first high-efficiency CuInSe2 thin-film solar cell by vacuum-depositing an evaporated n-type CdS on the crystalline p-CuInSe2, with a reported efficiency of $9.4 \%$ [11]. Since then, CIS solar cells have received widespread attention from researchers.
In 1993, the Advanced Industrial Science and Technology Institute (AIST) in Japan adopted an electron beam evaporation process followed by selenization to achieve the purpose of depositing an absorber layer on a flexible molybdenum foil, and the developed flexible solar cell has an efficiency of $8.3 \%$ [12]. In 1995, the National Renewable Energy Laboratory (NREL) embedded gallium into the CIS matrix to increase the band gap, open circuit voltage and fill factor of the absorber, thereby a highly efficient CIGS cell based on molybdenum coated alkali lime glass substrate was developed, and the reported efficiency is $17.1 \%$ [13]. In 1996, the International Solar Electricity Technology Corporation (ISET) used polyimide as a flexible substrate for the first time, and developed a CIGS cell through a two-stage process of sputtering metal presets, with a reported efficiency of $8.7 \%$ [14]. In 1999, NREL deposited a $\mathrm{ZnO} / \mathrm{CdS} / \mathrm{Cu}$ (In, Ga) $\mathrm{Se} 2 / \mathrm{Mo}$ polycrystalline thin film solar cell on a glass substrate, further increasing the efficiency to $18.8 \%$ [15]. Then, in 2008, NREL increased the efficiency to $19.9 \%$ again by reducing the recombination during the CIGS deposition process [16]. It can be seen that NREL researchers often report what significant improvement in efficiency of CIGS solar cells built on a rigid glass substrate has been achieved. In fact, so far, NREL is also a leading research institution in the field of CIGS solar cell development.

In 2010, AIST used a three-stage co-evaporation process to deposit the CIGS absorber layer on the molybdenum flexible substrate, thus achieving the highest efficiency $(14.6 \%)$ of the CIGS battery using the molybdenum substrate [17]. In 2011, Nanosolar and the Swiss Federal Institute of Materials Science and Technology (EMPA) adopted a non-vacuum low-cost printing setting and achieved the highest efficiency (17.1\%) of CIGS cells using aluminum foil substrates [18]. In 2012, EMPA achieved the highest efficiency (17.7\%) of CIGS cells using Mo/Ti-coated stainless-steel substrates [19]. In 2013, EMPA developed the most advanced flexible CIGS solar cell with the highest efficiency (20.4\%) built on polymer foil [20]. In 2017, AIST adopted a co-evaporation process on a rigid glass substrate and developed a new CIGS solar cell with an efficiency of $22.5 \%$ [21]. In 2019, Solar Frontier used vacuum deposition technology to develop CIGS solar cells with the highest efficiency (23.4\%) [22].

To show more clearly the development of CIGS thinfilm solar cells using rigid or flexible substrates, this paper specifically classifies and summarizes some key research work done by domestic and foreign researchers in the field of CIGS thin-film solar cells. The specific situations are shown in Table 1 and Table 2.

Table1. Development of CIGS thin-film solar cells with rigid substrates.

\begin{tabular}{|c|c|c|c|c|}
\hline Year & Substrate type & Efficiency value & Research institute & References \\
\hline 1976 & Rigid & $4.5 \%$ & University of Maine & {$[10]$} \\
\hline 1981 & Rigid & $9.4 \%$ & Boeing & {$[11]$} \\
\hline 1995 & Rigid & $17.1 \%$ & NREL & {$[13]$} \\
\hline 1999 & Rigid & $18.8 \%$ & NREL & {$[15]$} \\
\hline 2008 & Rigid & $19.9 \%$ & NREL & {$[16]$} \\
\hline 2017 & Rigid & $22.5 \%$ & AIST & {$[21]$} \\
\hline 2019 & Rigid & $23.4 \%$ & Solar Frontier & {$[22]$} \\
\hline
\end{tabular}


Table2. Development of CIGS thin-film solar cells using flexible substrates.

\begin{tabular}{|c|c|c|c|c|}
\hline Year & Substrate Type & Efficiency Value & Research Institute & References \\
\hline 1993 & Flexible & $8.3 \%$ & AIST & {$[12]$} \\
\hline 1996 & Flexible & $8.7 \%$ & ISET & {$[14]$} \\
\hline 2010 & Flexible & $14.6 \%$ & AIST & {$[17]$} \\
\hline 2011 & Flexible & $17.1 \%$ & Nanosolar \& EMPA & {$[18]$} \\
\hline 2012 & Flexible & $17.7 \%$ & EMPA & {$[19]$} \\
\hline 2013 & Flexible & $20.4 \%$ & EMPA & {$[20]$} \\
\hline
\end{tabular}

It can be seen from the above-mentioned development process of CIGS thin-film solar cells that rigid glass substrates have become the most widely used substrates for the deposition of absorber layers. Among many research institutions, NREL, a leading institution, has invested a lot of energy in the research of CIGS thin-film solar cells using rigid substrates. The most advanced CIGS battery with a rigid substrate currently available has an efficiency of up to $23.4 \%$ [22]. However, the current trend is to develop flexible solar cells built on flexible substrates of metal foil [23-25] and polyimide [14,23,26], and EMPA has spent a lot of thought on this aspect of research. Since the first attempt to develop flexible solar cells using molybdenum, titanium, and aluminum in 1992, the most advanced CIGS solar cell using a flexible substrate is built on a polymer foil with an efficiency of $20.4 \%$ [20].

\section{Commercial application}

At present, the preparation method of CIGS solar cells has been developed to a stage of industrial production for the purpose of commercialization. Some prestigious companies are already mass-producing CIGS modules built on glass substrates. These heavy rigid substrates are mainly used for grid-connected or stand-alone off-grid public facilities installed on roofs and land. Meanwhile, CIGS modules built on flexible substrates (such as polymers and stainless steel) are also currently produced. These CIGS modules built on flexible substrates are also used in roof installation and photovoltaic building integration. In transportation systems and charging applications. The existence of precision winding alignment technology improves the production potential of flexible substrates, and at the same time can reduce the size of the equipment required for different graded layers. However, so far, the development of standardized precision winding alignment deposition systems still cannot keep up with the development of CIGS solar cells, which is one of the most important reasons why the development of flexible substrates is not comparable to the development of rigid substrates.

Due to the difference in the generation kinetics in a large-scale environment, the current commercialized CIGS module can achieve a maximum efficiency of $17.4 \%$ [27], and there is still a large gap with the theoretical maximum efficiency (23.4\%) achieved in the laboratory scale.

\section{Key problems of CIGS solar cells}

In the existing CIGS solar cell research, there are still the following key issues that limit cell performance that require attention:

(1) The existing CIGS solar cells have a relatively complicated production process and need to go through a tedious production process. Moreover, the good rate of industrially produced CIGS solar cells is not high.

(2) There is an urgent need to develop and design a deposition process that can be performed under lower temperature and can be applied to flexible substrates.

(3) The CdS buffer layer deposited by chemical bath deposition method usually uses carcinogenic cadmium, so it poses a serious threat to health and hygiene. Although selenium does not exhibit high toxicity, selenium compounds (such as H2Se) are quite toxic. Therefore, how to find more environmentally friendly materials to manufacture CIGS solar cells is still a subject to be further studied.

(4) Material availability is also an issue that needs to be focused on in CIGS solar cell research. Most of the components in this type of solar cell are abundant in the earth's crust, except for the rare metal's indium and gallium. Moreover, these two rare metals have expensive prices.

The above several resource restrictions and ecological problems have had a considerable negative impact on the practical value of CIGS solar cells, and to a certain extent they have restricted their promotion and application in real life and business, and have led to our current failure to deploy CIGS solar cells on a terawatt scale. Therefore, in the future research of CIGS thin-film solar cells, it is necessary to start from the two aspects of material optimization and interface performance research to further improve the efficiency of CIGS thin-film solar cells.

\section{Acknowledgments}

This paper is one of the research progress and outcomes of the project "Optimization design of new energy vehicle power battery thermal management system" (2017KTSCX218).

\section{References}

1. D. Zhuang, G. Zhang, Research status and development prospect of CIGS thin film solar cells. Advanced Materials Industry 4, 43-48 (2005) 
2. B. Wang, P. Liu, W. Li, F. Ma, X. Liu, X. Chen, Progress in research of CIGS thin film solar cells. Materials Reports 19, 54-58 (2011)

3. A. Kowsar, S. F. U. Farhad, M. Rahaman, et al., Progress in major thin-film solar cells: Growth technologies, layer materials and efficiencies. International Journal of Renewable Energy Research (IJRER) 9, 579-597 (2019)

4. G. Regmi, A. Ashok, P. Chawla, P. Semalti, S. Velumani, S. N. Sharma, H. Castaneda, Perspectives of chalcopyrite-based CIGSe thin-film solar cell: a review. Journal of Materials Science: Materials in Electronics 31, 7286-7314 (2020)

5. Y. Xiao, Z. Xiong, M. Zhou, Device structure analysis of CIGS thin film solar cell. Electronic Components and Materials 11, 18-23 (2014)

6. B. Wang, P. Liu, W. Li, F. Ma, X. Liu, X. Chen, Research progress on buffer layer materials of CIGS thin film solar cell. Materials Reports 19, 136-140 (2012)

7. X. Huo, X. Mo, G. Chen, Deposition technologies of $\mathrm{Cd}$-free buffer layers in solar cells made of copper indium gallium diselenide films. Chinese Journal of Vacuum Science and Technology 9,834-840 (2012)

8. U. Rau, H. W. Schock, Cu (In, Ga) Se2 solar cells. Clean electricity from photovoltaics, 277-345 (2001)

9. S. Wagner, J. L. Shay, P. Migliorato, H. M. Kasper, CuInSe2/CdS heterojunction photovoltaic detectors. Applied Physics Letters 25, 434-435 (1974)

10. L. L. Kazmerski, F. R. White, G. K. Morgan, Thinfilm CuInSe2/CdS heterojunction solar cells. Applied Physics Letters 29, 268-270 (1976)

11. R. A. Mickelsen, W. S. Chen, Development of a $9.4 \%$ efficient thin-film CuInSe2/CdS solar cell. 15th photovoltaic specialists conference, 800-804 (1981)

12. B. M. Başol, V. K. Kapur, A. Halani, C. Leidholm, Copper indium diselenide thin film solar cells fabricated on flexible foil substrates. Solar Energy Materials and Solar Cells 29, 163-173 (1993)

13. J. R. Tuttle, M. A. Contreras, T. J. Gillespie, et al., Accelerated publication $17.1 \%$ efficient $\mathrm{Cu}$ (In, Ga) Se2-based thin-film solar cell. Progress in Photovoltaics: Research and Applications 3, 235-238 (1995)

14. B. M. Başol, V. K. Kapur, C. R. Leidholm, A. Halani, K. Gledhill, Flexible and light weight copper indium diselenide solar cells on polyimide substrates. Solar Energy Materials and Solar Cells 43, 93-98 (1996)

15. M. A. Contreras, B. Egaas, K. Ramanathan, J. Hiltner, A. Swartzlander, F. Hasoon, R. Noufi, Progress toward $20 \%$ efficiency in $\mathrm{Cu}$ (In, Ga) $\mathrm{Se} 2$ polycrystalline thin-film solar cells. Progress in Photovoltaics: Research and applications 7, 311-316 (1999)

16. I. Repins, M. Contreras, M. Romero, et al., Characterization of $19.9 \%$-efficient CIGS absorbers. 2008 33rd IEEE Photovoltaic Specialists Conference, 1-6 (2008, May)
17. S. Niki, M. Contreras, I. Repins, M. Powalla, K. Kushiya, S. Ishizuka, K. Matsubara, CIGS absorbers and processes. Progress in Photovoltaics: Research and Applications 18, 453-466 (2010)

18. P. Reinhard, A. Chirilă, P. Blösch, F. Pianezzi, S. Nishiwaki, S. Buechelers, A. N. Tiwari, Review of progress toward 20\% efficiency flexible CIGS solar cells and manufacturing issues of solar modules. 2012 IEEE 38th Photovoltaic Specialists Conference (PVSC) PART 2, 1-9 (2012, June)

19. F. Pianezzi, A. Chirilă, P. Blösch, et al., Electronic properties of $\mathrm{Cu}(\mathrm{In}, \mathrm{Ga}) \mathrm{Se} 2$ solar cells on stainless steel foils without diffusion barrier. Progress in Photovoltaics: Research and Applications 20, 253259 (2012)

20. M. A. Green, K. Emery, Y. Hishikawa, et al., Solar cell efficiency tables (version 42). Progress in Photovoltaics: Research and Applications 5, 827-837 (2013)

21. T. Kato, J. L. Wu, Y. Hirai, H. Sugimoto, V. Bermudez, Record efficiency for thin-film polycrystalline solar cells up to $22.9 \%$ achieved by Cs-treated $\mathrm{Cu}(\mathrm{In}, \mathrm{Ga})(\mathrm{Se}, \mathrm{S}) 2$. IEEE Journal of Photovoltaics 9, 325-330 (2018)

22. M. Nakamura, K. Yamaguchi, Y. Kimoto, Y. Yasaki, T. Kato, H. Sugimoto, Cd-free Cu (In, Ga)(Se, S)2 thin-film solar cell with record efficiency of $23.35 \%$. IEEE Journal of Photovoltaics 9, 1863-1867 (2019)

23. T. Satoh, Y. Hashimoto, S. I. Shimakawa, S. Hayashi, T. Negami, Cigs solar cells on flexible stainless steel substrates. Conference Record of the Twenty-Eighth IEEE Photovoltaic Specialists Conference-2000, 567-570 (2000, September)

24. R. Wuerz, A. Eicke, M. Frankenfeld, F. Kessler, M. Powalla, P. Rogin, O. Yazdani-Assl, CIGS thin-film solar cells on steel substrates. Thin Solid Films 517, 2415-2418 (2009)

25. C. Y. Shi, Y. Sun, Q. He, F. Y. Li, J. C. Zhao, Cu (In, $\mathrm{Ga}) \mathrm{Se} 2$ solar cells on stainless-steel substrates covered with $\mathrm{ZnO}$ diffusion barriers. Solar Energy Materials and Solar Cells 93, 654-656 (2009)

26. H. Zachmann, S. Heinker, A. Braun, A. V. Mudryi, V. F. Gremenok, A. V. Ivaniukovich, M. V. Yakushev, Characterisation of $\mathrm{Cu}$ (In, Ga) Se2-based thin film solar cells on polyimide. Thin Solid Films 517, 2209-2212 (2009)

27. A. Jäger-Waldau, PV status report 2017. https://publications.jrc.ec.europa.eu/repository/bitstr eam/JRC108105 /kjna28817enn.pdf. (1975) 